\title{
Feeding in fear: Indirect effects of predatory fish on macrophyte communities mediated by altered crayfish foraging behaviour
}

\author{
Tyler C. Wood ${ }^{1,2}$ (ID | Rosemary E. Kelley ${ }^{2,3}$ | Paul A. Moore
}

${ }^{1}$ Laboratory for Sensory Ecology, Department of Biological Sciences, Bowling Green State University, Bowling Green, Ohio

${ }^{2}$ University of Michigan Biological Station, Pellston, Michigan

${ }^{3}$ University of Michigan Program in the Environment, Ann Arbor, Michigan

${ }^{4} J . P$. Scott Center for Neuroscience, Mind and Behavior, Bowling Green State University, Bowling Green, Ohio

\section{Correspondence}

Paul A. Moore, Laboratory for Sensory Ecology, Department of Biological Sciences, Bowling Green State University, Bowling Green, $\mathrm{OH}$.

Email: pmoore@bgsu.edu

Funding information

Bowling Green State University Faculty Research Committee Building Strength Award; University of Michigan Biological Station Marian P. and David M. Gates Graduate Student Endowment Fund; Fulbright Association

\begin{abstract}
1. The threat of predation influences decisions made by prey animals and alters the way that prey interact with other species in their environment. Animals often alter their foraging behaviour in response to a predatory threat by increasing or decreasing food consumption or by changing their feeding preferences to focus on foods that limit their exposure to the threat. Changes in grazing pressure and diet selectivity can have significant impacts on the abundance and diversity of the prey's food resources. In this study, we examined the indirect effects of a predatory fish on macrophyte biomass, mediated by crayfish responses to predator odours.
\end{abstract}

2. Largemouth bass (Micropterus salmoides, Centrarchidae) were housed in flow-through stream mesocosms to produce odour cues that initiated a nonconsumptive effect on rusty crayfish (Faxonius rusticus, Cambaridae) held in an adjacent section of the stream. Crayfish were offered three species of macrophytes (Myriophyllum exalbescens, Haloragaceae; Elodea canadensis, Hydrocharitaceae; Chara spp., Characeae) and were allowed to graze for $48 \mathrm{hr}$. Consumption of each plant species was measured by weighing the plant samples before and after every trial. The plant samples were further analysed for total phenolic content using the Folin-Ciocalteu method. Foraging and shelter use behaviours were quantified by analysis of video recordings for time spent foraging in the mesocosm and time spent in the shelter zone of the mesocosm.

3. Crayfish consumed greater quantities of macrophyte tissue when predator cues were present, and this result was unexpected and is contrary to most observations in the literature.

4. When threatened, the crayfish also showed a preference for two of the macrophyte species, which did not exist in trials without bass odour. This could be due to differences in total phenolic content among the three plant species tested.

5. The results provide evidence for a strong indirect effect of predatory fish on the macrophyte community mediated by changes in crayfish behaviour under threat. Crayfish act as keystone species in stream ecosystems; thus, changes in their foraging behaviour and dietary preferences caused by exposure to predator odour cues could have important effects on macrophyte communities in lotic systems.

KEYWORDS

chemical cues, indirect effect, largemouth bass, macrophytes, predator-prey, rusty crayfish 


\section{1 | INTRODUCTION}

Nonconsumptive effects (NCE) occur when prey alter their behaviour in response to detection of predator-related stimuli (Brown, Laundré, \& Gurung, 1999). Nonconsumptive effects can alter trophic cascades and have larger impacts on food webs than direct consumption of prey by altering prey behaviour, morphology or physiology (Peacor, Peckarsky, Trussell, \& Vonesh, 2013; Preisser, Bolnick, $\&$ Benard, 2005). One of the ways in which prey change their behaviour under the threat of predation is by altering their foraging behaviour (Laundré, Hernández, \& Ripple, 2010). The reintroduction of wolves (Canis lupus) into Yellowstone National Park has caused the elk (Cervus canadensis) population to switch from feeding on aspen (Populus tremuloides) saplings in the river bottoms and lowlands to browsing farther up in the mountain valleys (Laundré et al., 2010; Ripple \& Beschta, 2006). Similarly, in stream environments, the presence of piscivorous bass (Micropterus salmoides and Micropterus punctulatus) limits the foraging of herbivorous minnows (Campostoma anomalum) and promotes the growth of filamentous algae (primarily Spirogyra spp. and Rhizoelonium spp.; Power \& Matthews, 1983). These increases in plant growth, ultimately resulting from the presence of a predator, are called trait-mediated indirect interactions (TMII; Abrams, 1995). Foraging behaviour is a trait of prey that when altered changes their impact on food resources (Peacor \& Werner, 2001). Thus, the predator has an indirect effect on the prey's food resource (Abrams, 1995). For example, prairies with spider (Pisaurina mira) populations have increased grass diversity because of a feeding strategy adopted by grasshoppers (Melanoplus femurrubrum) to avoid spider webs (Schmitz, 1998). Cladocerans (Daphnia, Diaphanosoma and Ceriodaphnia) are more abundant when piscivores ( $M$. salmoides) are present, because planktivorous fish (Lepomis macrochirus) spend more time in vegetated refuge (Turner \& Mittelbach, 1990). These examples of TMlls illustrate how the presence of a predator alters the foraging behaviour of prey populations (Grabowski, 2004; Sih, 1982; Trussell, Ewanchuk, \& Bertness, 2003). Indirect effects, mediated through NCEs, can only occur if prey detect and respond to the presence of predatory cues within the environment (Luttbeg \& Trussell, 2013).

Before NCEs can manifest, prey must first detect the predator's presence by sensing cues released by the predator (Turner \& Peacor, 2012). The detectability of cues is ultimately based on the types of cues produced and their transmission throughout the environment (Atema, 1988; Bouwma \& Hazlett, 2001; Moore \& Crimaldi, 2004). Predator attributes can influence the types of signals that are released into the environment (Persons \& Rypstra, 2001). Larger predators may produce cues that are greater in magnitude and thus more likely to be detected by prey (Hill \& Weissburg, 2013). Different predators release cues of varying quality and composition, and prey will not respond the same way to two predators of different species (Turner, Fetterolf, \& Bernot, 1999). There is also variation within and among prey species in their ability to detect predatory stimuli. If the intensity and composition of the cue is sufficient to exceed the sensory threshold for a given prey, then the animal will respond to the cue, and attempt to avoid the predator. In aquatic environments, most predator-prey interactions and NCEs are mediated through chemical signals (Brönmark \& Hansson, 2000; Derby \& Sorensen, 2008; Hay \& Kubanek, 2002).

Crayfish are ideal model organisms for testing the indirect effects of predator odours in aquatic environments because crayfish are highly sensitive to olfactory stimuli (Gherardi, Mavuti, Pacini, Tricarico, \& Harper, 2011; Hazlett \& Schoolmaster, 1998; Keller, Tomba, \& Moore, 2001). Adult crayfish also feed primarily on macrophytes (Hogger, 1988). Crayfish are known to severely impact the density and diversity of macrophyte beds when their foraging is unchecked by natural predators (Carreira, Segurado, Laurila, \& Rebelo, 2017; Feminella \& Resh, 1989; Lodge, Kershner, Aloi, \& Covich, 1994). Thus, predators must have an important influence on crayfish behaviour and population dynamics in locations where stable populations of crayfish and macrophytes coexist. We hypothesise that the consumption of macrophyte biomass by crayfish will be reduced in the presence of predatory threats. This effect will be mediated by a reduction in foraging effort by the crayfish under threat conditions.

Crayfish are also known to be selective in the herbivory component of their diet (Carreira, Dias, \& Rebelo, 2014; Cronin et al., 2002; Nyström \& Strand, 1996). Plants with low concentrations of phenolic compounds are preferred by crayfish over those with greater phenolic content (Bolser, Hay, Lindquist, Fenical, \& Wilson, 1998). Over time, selective grazing by crayfish may reduce the abundance of their preferred macrophyte species, replacing them with species that are not commonly grazed (Carreira et al., 2014; Moretto \& Distel, 1999; Parsons, Harvey, \& Johnson, 1991). However, if crayfish shift their dietary preferences for different macrophytes under threat of predation, then the presence of threats would indirectly affect the distribution and diversity of macrophyte species in aquatic habitats (Rodríguez, Bécares, Fernández-Aláez, \& FernándezAláez, 2005). Previous work in a variety of other animals shows changes in food preferences under threating conditions as reviewed in Lima and Dill (1990). Such a disturbance could result in significant changes in aquatic habitat structure and the complexity of the environment because macrophytes are diverse in their shapes and forms (Taniguchi, Nakano, \& Tokeshi, 2003; Warfe \& Barmuta, 2006). Thus, we hypothesise that crayfish will focus their foraging effort on more preferred macrophyte species when threatened, resulting in larger differences in biomass loss between macrophyte species.

\section{2 | METHODS}

\subsection{Collection and housing of crayfish, bass and aquatic plants}

A total of 160 form II (nonreproductive) female rusty crayfish (F. rusticus) were collected from Maple Bay of Burt Lake, in Cheboygan County, Michigan $\left(45.4873^{\circ} \mathrm{N}, 84.7065^{\circ} \mathrm{W}\right)$. All crayfish (postorbital 
length $3.21 \pm 0.02 \mathrm{~cm}$ [mean \pm SEM]) had intact appendages and were free of any visible signs of disease. The crayfish were held in a flow-through stock tank $(200 \times 60 \times 60 \mathrm{~cm}$ : I $\times w \times d)$ filled with 640 I of water from the Maple River filtered through elastic nylon mesh. Crayfish were allowed to feed on natural detritus in the stock tank from the river water. Twenty short PVC pipe sections provided shelter for crayfish in the stock tank. Before use in a trial, crayfish were marked with an identifying symbol drawn in nontoxic whiteout pen (BIC ${ }^{\circledR}$ Wite-Out ${ }^{\circledR}$ Shake 'N Squeeze ${ }^{\mathrm{TM}}$ Correction Pens). Each crayfish was only used in a single trial.

Largemouth bass ( $M$. salmoides) were utilised as a source of predator odour. Forty-eight bass (total length $=15.86 \pm 0.20 \mathrm{~cm}$ [mean \pm SEM]) were purchased from Harrietta Hills Trout Farm LLC, in Harrietta Hills, Michigan. The bass were maintained in an identical, but separate 640 I flow-through stock tank $(200 \times 60 \times 60 \mathrm{~cm}:$ I $\times$ $\mathrm{w} \times \mathrm{d}$ ) filled with water from the Maple River at a density of approximately one bass per $13 \mathrm{l}$. The stock tank was divided into half by a plastic egg crating partition so that bass used in previous trials could be separated from unused bass. Given the number of trials and number of bass, some individual bass were reused. Any individual bass was not used in more than two trials, with a minimum of $24 \mathrm{hr}$ between uses.

Bass were fed pellets made by pulverising whole frozen rusty crayfish in a coffee grinder. The resulting crayfish slurry was then partitioned into approximately $0.5 \mathrm{ml}$ portions before freezing. The frozen pellets were offered once daily at a rate of one pellet per bass, by broadcasting into the stock tank. All bass were fed a diet of crayfish pellets for at least 2 days before use in any trials. Feeding of a conspecific prey diet was intended to increase the threat strength of the predator odour stimulus (Chivers, Wisenden, \& Smith, 1996; Turner, 2008; Weissburg, Poulin, \& Kubanek, 2016).

Three species of aquatic plants including American waterweed (E. canadensis), muskgrass (Chara spp.) and northern watermilfoil (M. exalbescens) were collected from South Fishtail Bay of Douglas Lake, in Cheboygan County, Michigan $\left(45.5618^{\circ} \mathrm{N}, 84.6762^{\circ} \mathrm{W}\right)$. Plants were collected by casting a macrophyte sampling rake from a boat into submerged vegetation mats. The macrophytes were stored until needed in three 100 I flow-through plastic drums fed with unfiltered water from the Maple River. The macrophyte storage drums were situated outdoors in direct sunlight, away from any overhead cover to prevent shading of plants. Plants were maintained from 23 June 2017 until 12 August 2017. All five species (bass, crayfish, macrophytes) are quite common in this part of the midwest of the United States and co-occur across a wide diversity of habitats.

\subsection{Experimental design and arenas}

The experiment followed a $2 \times 2$ fully factorial design with bass presence or absence as the first factor and crayfish presence or absence as the second factor. A total of $n=80$ trials were run across four different treatments. All three macrophyte species were present in every trial. There were $n=20$ control trials which included no animals, $n=20$ trials including only bass, $n=20$ trials including only crayfish, and $n=20$ trials with both bass and crayfish present.

Eight identical flow-through stream mesocosms $(200 \times 60 \times$ $25 \mathrm{~cm}$ : $(\times w \times d)$ were constructed from cinderblocks, lined with $0.1 \mathrm{ml}$ thick plastic sheeting and $5 \mathrm{~cm}$ of gravel substrate at the University of Michigan Biological Station Stream Research Facility in Pellston, Michigan. Mesocosms were fed from 208 I plastic drums functioning as constant head tanks filled with filtered water from the Maple River. Water from the head tanks was delivered to the mesocosms through two $10 \mathrm{~mm}$ diameter garden hoses per mesocosm, each regulated by a spigot at the head tank (flow rate $=0.26 \pm 0.01$ $\mathrm{l} / \mathrm{s}$ [mean $\pm \mathrm{SEM}]$ ). Each mesocosm was further divided into half by a screened opening in a partial wall that permitted water flow but inhibited animal movement. The two halves were defined as the predator section and the crayfish section (Figure 1). The predator sections $(80 \times 60 \times 25 \mathrm{~cm}: \mathrm{I} \times \mathrm{w} \times \mathrm{d})$ received the inflow water directly from the head tank hoses.

The crayfish sections $(100 \times 60 \times 25 \mathrm{~cm}: I \times w \times d)$ were filled with water flowing through the screened wall from the predator section. The crayfish sections also contained four PVC half-pipe shelters $(10 \times 8.5 \times 4 \mathrm{~cm}: \mathrm{I} \times \mathrm{w} \times \mathrm{d})$ placed at the down current end. Similar shelters have been used in other crayfish behaviour studies (Chibucos, Wofford, \& Moore, 2015; Jurcak \& Moore, 2014). A screened opening at the down current end of the crayfish sections allowed water to flow out of the system and back to the Maple River.

Treatments were alternated among the eight mesocosms such that each mesocosm produced a roughly equal number of trials for every treatment type. The systems are flow through and any odours present from a previous trial are naturally flushed overnight. Based on the flow velocity and the volume of the mesocosms, water turnover in each stream occurs in approximately $17 \mathrm{~min}$.

An infrared DVR security camera (Swann SWDVK-430004) was mounted above each of the eight mesocosms to capture the nocturnal behaviours of crayfish. The mesocosms were illuminated from above with low intensity, red filtered light bulbs. A black utility tarp awning $(9 \times 6 \mathrm{~m})$ covered all eight of the experimental mesocosms. The awning limited direct overhead sunlight exposure and prevented surface disturbance during rain events. Sunlight entered the system at the sides of the tanks. The awning also served to shield video cameras and lighting equipment from weather and from glare by moonlight and starlight.

\section{3 | Experimental protocol}

Experimental trials began 27 June 2017 and were concluded on 14 August 2017. All trials lasted 48 hours in duration. Set-up began at approximately 8:00 AM on the first day of a trial and was completed by 2:00 PM. On the second day of the trial, the mesocosms were only disturbed briefly to remove detritus from the screens of the dividing wall and outflow openings (detritus was removed once daily in all mesocosms). Trials were dismantled beginning at 8:00 AM and completed by 11:30 AM on the third day of the trial. 


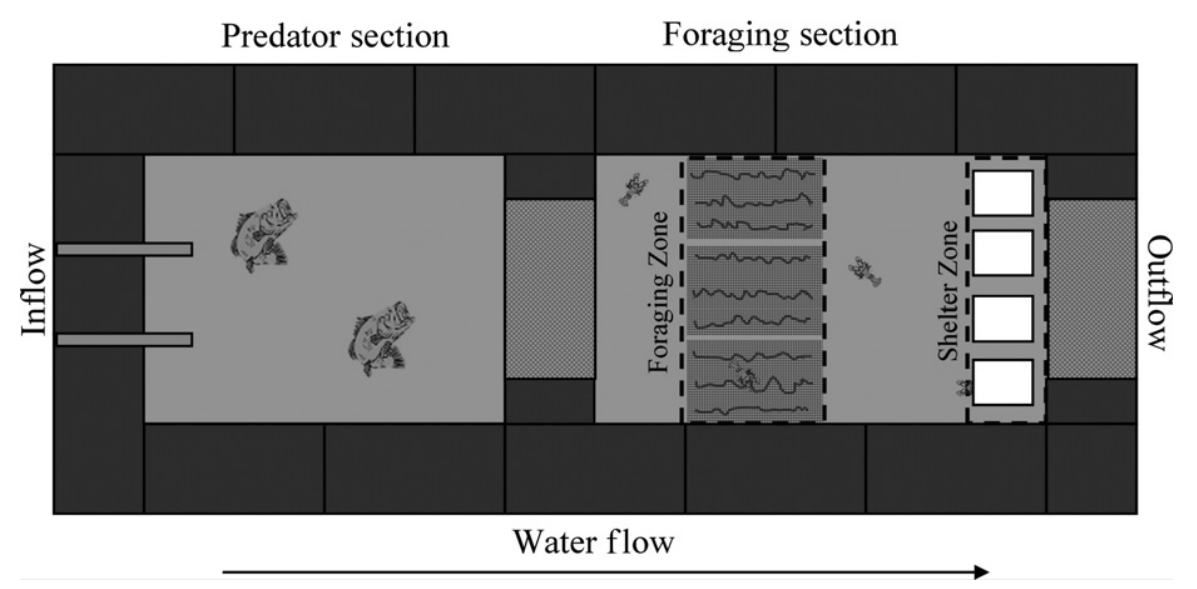

FIGURE 1 Experimental Mesocosm. Filtered river water enters from a constant head tank through the inflow hoses on the left. Water resides temporarily in the predator section before flowing through a screened opening into the crayfish section. Water then flows out of the screened outflow on the right. The boxes outlined with dashes define the boundaries of the plant resource zone (gridded area) and the shelter zone (white boxed area)

In trials that included predator odour, two bass were placed into the predator section of each mesocosm. The bass were placed in the predator sections at least $2 \mathrm{hr}$ before the crayfish were introduced to the crayfish sections. Introduction of bass into the mesocosms allowed the crayfish sections to fill with water containing bass odour before crayfish were introduced, so that there would not be any delay in odour exposure.

Only visually fresh macrophyte samples were selected from the storage system to reduce any effect of plant condition on herbivore preference. Macrophyte samples were selected that showed bright coloration and fullness of leaf structure. Three $25 \mathrm{~cm}$ length stems of each macrophyte species were utilised per trial. Surface water was removed from the macrophyte stems using a salad spinner. This device uses centrifugal force to throw water from the surfaces of vegetation. After drying, each set of macrophyte stems was weighed to the nearest $0.01 \mathrm{~g}$.

Each macrophyte stem was attached to a glass stir rod $(25 \times 0.6 \mathrm{~cm}$ : I $\times$ dia. $)$ with 26 gauge green-painted steel floral wire.
Three stir rods, one for each plant species, were then attached to a hardware cloth bracket $(24 \times 19 \mathrm{~cm}$ : I $\times$ w). The positions of each macrophyte species on a bracket were rotated to prevent any false preferences related to plant position. Three plant brackets were then placed into the up current third of each crayfish section, directly onto the substrate. The configuration of the brackets within the crayfish section was rotated between trials to reduce any feeding bias caused by the location of plant samples in the arena (Figure. 2). Attaching the macrophyte samples to brackets prevents the tissue samples from floating away from the crayfish, and it also prevents the crayfish from dragging the samples into the shelter zone to feed.

Four crayfish were selected from their holding tank for use in each trial that included crayfish presence as a factor. The postorbital carapace length of each crayfish was measured to the nearest $0.5 \mathrm{~mm}$. Each crayfish was marked for individual identification and added to the crayfish section of the mesocosm.

During trials involving crayfish, overhead video cameras recorded the nocturnal behaviours of the crayfish for $4 \mathrm{hr}$ each night. The
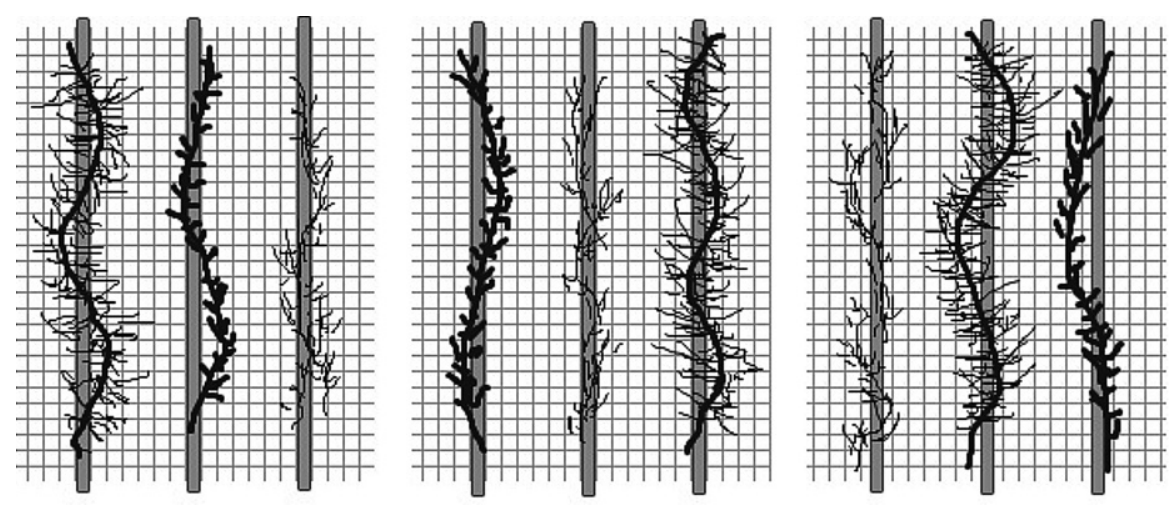

FIGURE 2 Plant Resource Zone Example. The illustration above demonstrates one of three possible arrangements of macrophyte stems offered in the plant resource zone during a trial. Starting on the left, the first bracket shows M. exalbescens, E. canadensis and Chara spp. The second bracket shows a shift in the order, E. canadensis, Chara spp. and M. exalbescens. The third bracket shows Chara spp., M. exalbescens and E. canadensis. The three wire brackets can be reordered to give two additional arrangements of plant species 
cameras began recording at 00:00 and stopped at 04:00 each night, thus recording a total eight hours of video per trial in two-four hour blocks.

After the 48-hr trials were complete, all crayfish were removed from the system. The crayfish were then euthanised by freezing. The macrophyte samples were removed from the streams and surface dried in the salad spinner before weighing a second time. All macrophyte samples were flash frozen with liquid nitrogen and were stored in a freezer at $-80^{\circ} \mathrm{C}$. A subset of the macrophyte samples ( $n=5$ per treatment) were randomly selected for total phenolic content analysis using the Folin-Ciocalteu method (Folin \& Ciocalteu, 1927). This technique uses colorimetry to analyse methanol extracts of freeze-dried plant tissues that have been treated with Folin's phenol reagent against a gallic acid standard. Previous research has shown that plant-derived phenolic compounds deter herbivory by crayfish (Bolser et al., 1998).

\subsection{Data collection}

The masses of plant tissue samples for each macrophyte species were recorded before and after the 48-hr duration of each trial. To quantify changes in macrophyte biomass, the mass of each sample after the trial period was subtracted from its initial mass before the trial. These differences were then normalised by the initial mass to calculate a percentage of biomass change.

Per cent Biomass Change $=\left(\left(W_{f}-W_{i}\right) / W_{i}\right) * 100$

where $W_{i}$ is the initial mass of three stems of one macrophyte species used in a single trial and $W_{f}$ is the final mass of the same three macrophyte stems at the end of the trial. Positive percentages would indicate an increase in biomass, while negative percentages would indicate a loss of biomass. Using this technique, we do not assume that autogenic plant growth is the same across treatment conditions which may cause plants to grow at different rates from controls due to grazing pressure or the presence of nutrients released by animals in the system.

The overall nocturnal activity of the crayfish was examined in an effort to assess how the presence of bass altered their behaviour. Video recordings were manually scored for behaviours by a reviewer blind to the treatment. Two separate behaviours were recorded for the crayfish: foraging and shelter use. A crayfish was scored as either foraging or using shelters when and only when the entire marker (located on its carapace) was within the foraging zone or shelter zone (Figure 1). Given the clarity limitations of the overhead camera, we are uncertain of whether the crayfish is actually foraging while in the foraging zone. So for ease of communication, we are defining the term foraging as when the animal was present in the zone with the plants.

From this analysis, a total of four different behavioural measures are recorded: time in foraging zone, transition into or out of foraging zone, time in shelter zone, transition into or out of shelter zone. Transitions into or out of zones were chosen as a proxy for overall activity of the crayfish.
From these initial behavioural measures, secondary behavioural measures were calculated and used for statistical analysis. The total foraging effort was calculated by multiplying the time spent foraging by the number of crayfish foraging. For example, if the total time that only one crayfish was found within the foraging zone for a night was $90 \mathrm{~min}$, then that foraging effort was 90 crayfish minutes. If the total time that two crayfish were found in the foraging zone was $15 \mathrm{~min}$, then that effort was 30 crayfish minutes. After these multiplications, the values were summed to produce total foraging effort. This number was divided by 960 crayfish minutes. This value $(960$ crayfish minutes) was the total maximum amount of foraging effort the four crayfish could demonstrate ( $4 \mathrm{hr} \times$ four crayfish). This final result produced a proportion of total foraging effort. This proportion provides insight into how the population of crayfish responded to the presence or absence of bass. Values for total sheltering effort were calculated in the same manner as total foraging effort.

\subsection{Statistical analysis}

Changes in plant biomass (per cent biomass loss) were analysed using a nonlinear mixed model in R (Bates, Maechler, Bolker, \& Walker, 2015; R Core Team, 2018). The plant biomass model was constructed with full interactions using three fixed factors (bass treatment, crayfish treatment and macrophyte species) and two random factors (trial number and mesocosm). The trial number as a random factor accounted for the interdependence of the macrophyte species and the mesocosm accounted for the different mesocosm effects. When significant differences were found with the interaction terms, differential contrasts were used with a Tukey HSD post hoc test to determine where significant differences existed (Hothorn, Bretz, \& Westfall, 2008; R Core Team, 2018).

A three-way analysis of variance was used to test the effects of crayfish presence or absence, bass presence or absence, and plant species on the total phenolic content of a subset of macrophyte samples (R Core Team, 2018). A Tukey HSD post hoc test was used to determine which groups were significantly different (Hothorn et al., 2008; R Core Team, 2018).

The crayfish behaviour data were analysed similarly to the changes in plant biomass. A nonlinear mixed model analysis in $\mathrm{R}$ was performed with two fixed effects (bass treatment and trial night) and two random factors (trial number and mesocosm). Significant differences in interactions terms were found using a Tukey HSD post hoc test (Bates et al., 2015; Hothorn et al., 2008; R Core Team, 2018).

\section{RESULTS}

\section{1 | Macrophyte consumption}

There was an overall interaction effect of bass presence or absence, crayfish presence or absence, and macrophyte species on changes in plant biomass $\left(F_{(2,152,0.05)}=5.202, p=0.007\right)$.

Comparisons of biomass changes within macrophyte species across treatments indicate that crayfish consumed significantly 
more of E. canadensis when odours from the bass were present (Tukey HSD test, $p<0.001$; Figure 3, left panel; Table 1, top left). The biomass of Chara spp. was also reduced a marginally significant amount by crayfish grazing when bass odours were present compared to trials without bass odours (Tukey HSD test, $p=0.058$; Figure 3, centre panel; Table 1, top centre). Myriophyllum exalbescens did not show a significant difference in biomass consumption by crayfish under bass present or bass absent conditions (Tukey HSD test, $p=0.99$; Figure 3, right panel; Table 1, top right).

When crayfish consumption of macrophytes was compared across species, crayfish did consume a significantly greater percentage of $E$. canadensis than $M$. exalbescens in bass odour present trials (Tukey HSD test, $p<0.001$; Table 1, bottom centre). The crayfish also consumed a significantly greater percentage of Chara spp. biomass than $M$. exalbescens when bass odours were present (Tukey HSD test, $p<0.001$; Table 1, bottom right). However, crayfish did not consume significantly different percentages of the biomass of E. canadensis and Chara spp. (Tukey HSD test, $p=0.99$; Table 1, bottom left).

Plant species had a significant effect on the total phenolic content of the macrophyte samples tested (three-way ANOVA, $p<0.001)$. The mean total phenolic content of $M$. exalbescens across all treatments was $11.26 \mathrm{mg} / \mathrm{g}$ in gallic acid equivalents. M. exalbescens contained significantly more phenolics than either E. canadensis or Chara spp. (Tukey HSD test, $p<0.001$ and $p<0.001$, respectively). The mean total phenolic content of E. canadensis was $1.88 \mathrm{mg} / \mathrm{g}$ in gallic acid equivalents. The mean total phenolic content for Chara spp. was $0.34 \mathrm{mg} / \mathrm{g}$ in gallic acid equivalents. There was no significant difference in the phenolic content of E. canadensis and Chara spp. (Tukey HSD test, $p=0.468$ ).

\section{2 | Crayfish behaviour}

There was a significant effect of bass presence on the number of crayfish transitions into and out of the plant and shelter resource zones (linear mixed model fit by REML, $p=0.023$ ). The number of transitions between the resource zones decreased from an average of 232 transitions per night without bass to an average of 190 transitions per night with bass present. A significant effect of night of observation was also detected on the number of transitions. Crayfish crossed the boundaries of the resource zones significantly more on

TABLE 1 Effects of predator odour on macrophyte consumption

\begin{tabular}{|c|c|c|c|c|}
\hline & \multicolumn{4}{|c|}{ Within species comparison } \\
\hline & $\begin{array}{l}\text { Elodea vs. } \\
\text { Elodea }\end{array}$ & \multicolumn{2}{|c|}{ Chara vs. Chara } & $\begin{array}{l}\text { Milfoil vs. } \\
\text { Milfoil }\end{array}$ \\
\hline \multirow{3}{*}{$\begin{array}{l}\text { Bass Odour } \\
\text { Absent vs. Present }\end{array}$} & $p<0.001$ & \multicolumn{2}{|c|}{$p=0.05822$} & $p=0.99990$ \\
\hline & \multicolumn{4}{|c|}{ Across species comparison } \\
\hline & \multicolumn{2}{|c|}{ Elodea vs. Chara } & $\begin{array}{l}\text { Milfoil vs. } \\
\text { Elodea }\end{array}$ & $\begin{array}{l}\text { Milfoil vs. } \\
\text { Chara }\end{array}$ \\
\hline $\begin{array}{l}\text { Bass Odour } \\
\text { Present vs. Present }\end{array}$ & \multicolumn{2}{|c|}{$p=0.99998$} & $p<0.001$ & $p<0.001$ \\
\hline
\end{tabular}

The top table displays within species $p$ values from Tukey HSD multiple comparisons following a linear mixed model analysis. These comparisons demonstrate changes in the consumption of each macrophyte species between predator absent and predator present conditions. The bottom table displays across species $p$ values from Tukey HSD multiple comparisons following a linear mixed model analysis. These comparisons demonstrate changes in the relative percentage of each macrophyte species consumed under the influence of the predator.
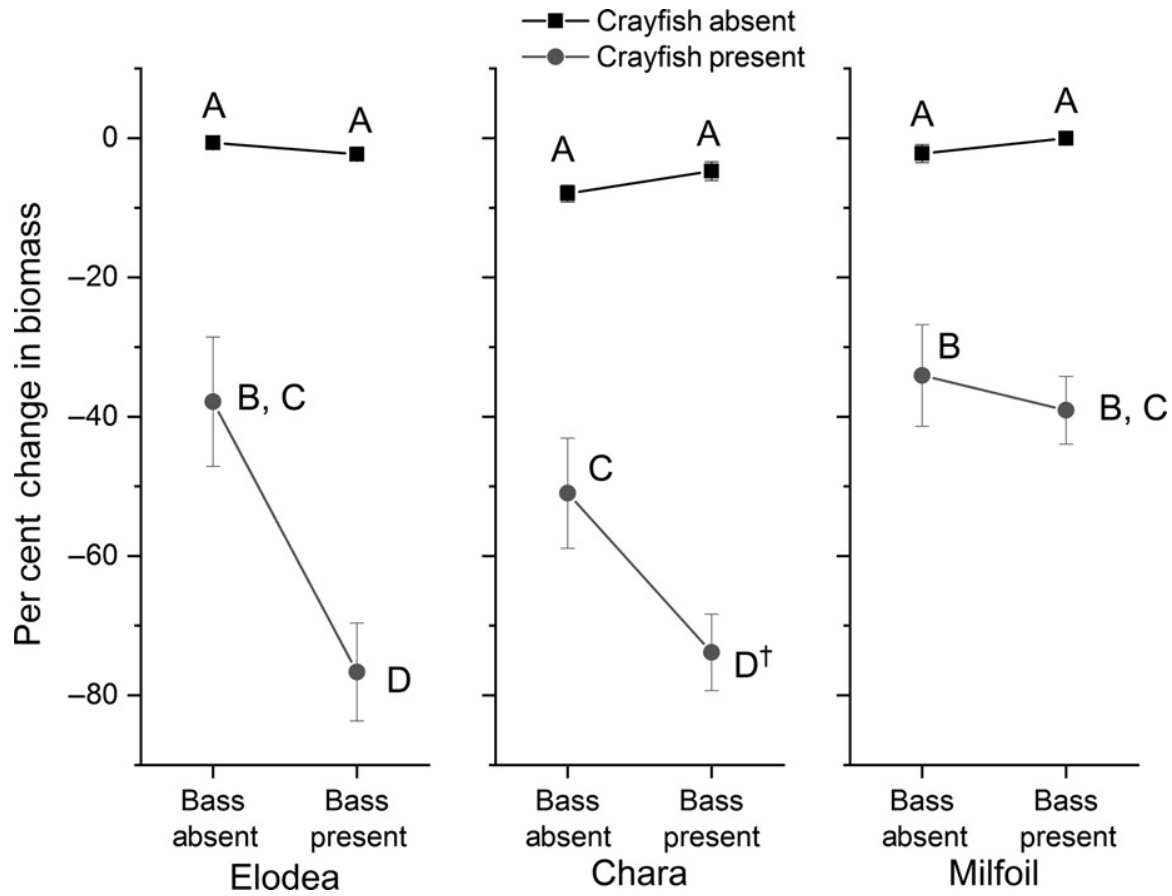

FIGURE 3 Effects of Crayfish Grazing and Bass Odour on Macrophyte Biomass. Per cent change in macrophyte biomass (mean \pm SEM) resulting from crayfish absence (black closed squares) and crayfish presence (grey closed circles). The left two points in each plot indicate trials with bass absent, and the right two points are trials with bass present. Points labelled with different letters indicate a significant difference resulting from a linear mixed model analysis followed by a Tukey HSD post hoc test $(p<0.05)$. 'See Table 1 for within species comparison for Chara spp 
the first night of the trial (mean $=232$ transitions) than on the second night of the trial (mean = 190 transitions).

Crayfish displayed a marginally greater percentage of total foraging effort when bass were present as opposed to when bass were absent (Tukey HSD test, $p=0.051$ : Figure 4, left panel). Crayfish significantly decreased the percentage of total shelter use when bass were present as opposed to when bass were absent (Tukey HSD test, $p<0.005$ : Figure 5, left panel).

\section{DISCUSSION}

\subsection{Effect of predator odour on macrophyte consumption by crayfish}

The findings from this study clearly demonstrate that crayfish herbivory was heavily modified by the presence of predatory cues. This is seen in the increased consumption of macrophytes when fish were present in the trials. In addition, crayfish became more selective in their herbivory when predatory cues were present. Crayfish consumed significantly greater percentages of E. canadensis and Chara spp. biomass as opposed to M. exalbescens in trials when bass were present. The mechanism that underlies both the increased herbivory and change in selectivity of consumption appears to be alterations in foraging behaviour. In the presence of predatory odour, crayfish significantly decreased their movements between resource zones, while increasing the amount of time spent in the foraging zone of the mesocosm. Crayfish also significantly decreased the time spent in the shelter zone when predator odours were present. The findings of increased foraging behaviours and decreased shelter use under threat are contrary to our hypotheses and contrast with many prior findings in the literature. However, the decrease in overall activity and the change in macrophyte preferences under threat were expected.

Animals responding to predatory threats are known to show elevated stress, evidenced by increased stress hormone levels (Barton, 2002; Pauwels, Stoks, \& De Meester, 2005; Sheriff, Krebs, \& Boonstra, 2009). It is possible that the metabolic cost of stress responses requires an increase in food consumption (Hawlena \& Schmitz, 2010). Thus, crayfish could be feeding more because of the metabolic cost of physiologic stress imposed by the predator. Some animals respond to NCEs by altering their morphology to make themselves more difficult for predators to consume (Brönmark \& Miner, 1992; Tollrian, 1995). Despite the time involved in morphological changes, this response can reduce the likelihood of predation in the future (Nilsson, Brönmark, \& Pettersson, 1995). Largemouth bass are gape-limited predators, and increased foraging in crayfish may be an attempt to accelerate growth in order to escape the gape limitation of a potential predator (Hambright, 1991; Urban, 2007). Finally, the crayfish in our system are only being exposed to chemical stimuli. The presence of both mechanical and visual stimuli, along with chemical stimuli, may produce different foraging and shelter use results. Regardless of the mechanism driving changes in crayfish behaviour, the differences in the increased foraging effort as well as

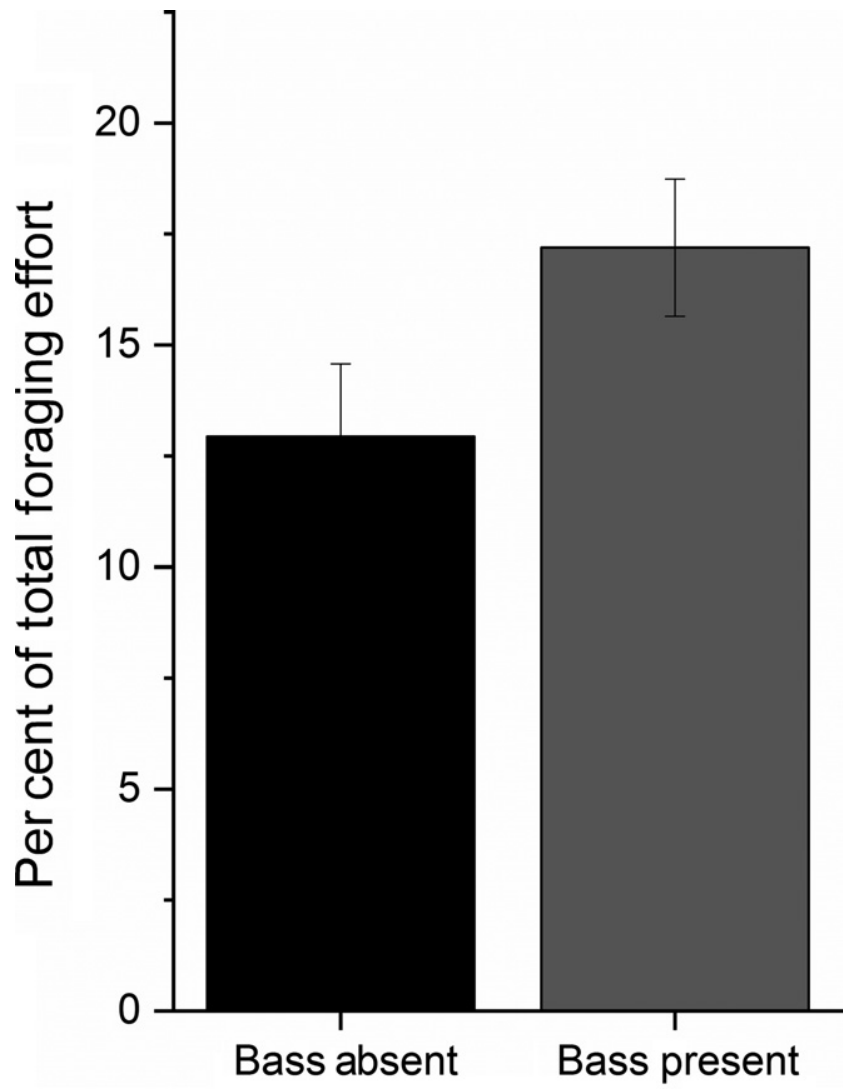

FIGURE 4 Bass Odour Influence on Crayfish Foraging Behaviour. Effects of bass absence (black) and presence (grey) on total foraging effort (mean \pm SEM: $p=0.0518$ )

the change in selectivity of the consumption of macrophytes could lead to changes in the macrophyte communities of streams.

\subsection{Consequences for aquatic systems}

Increased grazing pressure by crayfish under threat of predation will have a negative influence on the biomass of macrophytes in aquatic habitats. Macrophytes comprise the bulk of the diet in adult crayfish (Abrahamsson, 1966; Hogger, 1988), and the effects of increased grazing pressure from crayfish invasions are known to greatly reduce the biomass of macrophyte communities (Feminella \& Resh, 1989; Gherardi \& Acquistapace, 2007; Lodge \& Lorman, 1987). Similar losses of biomass might be expected if crayfish increase their consumption of macrophytes in response to predatory stimuli. Crayfish in the current study consumed nearly double the plant biomass when predators were present. Such significant reductions in macrophyte biomass would result in the loss of a key food resource for many herbivorous invertebrates, fish and waterfowl as reviewed by Lodge (1991). Macrophytes also provide surface area for colonisation by epiphytic algae, bacteria and protists, which are key food resources for many aquatic invertebrates (Soszka, 1975). Decreased macrophyte abundance could change ecological interactions within the community of epiphyton feeding fauna (Brönmark, 1990; Gresens, 1995; Wallace \& Webster, 1996). Reduced area for 


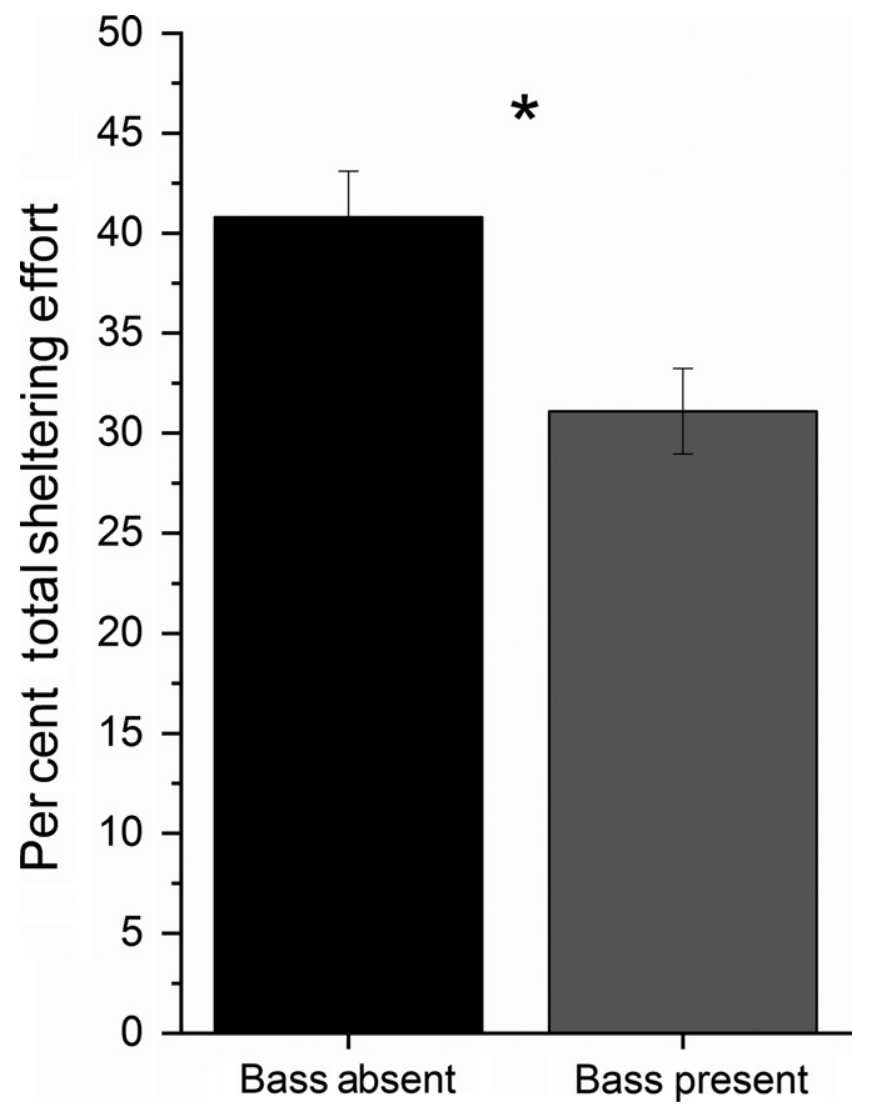

FIGURE 5 Bass Odour Influence on Crayfish Sheltering Behaviour. Effects of bass absence (black) and presence (grey) on total sheltering effort (mean \pm SEM: $p<0.005$ )

epiphyton grazing would increase competition between aquatic herbivores, which are known to compete through exploitation and interference for epiphyton resources (Gresens, 1995; Lamberti, Ashkenas, Gregory, \& Steinman, 1987). Macrophyte losses that translate to reductions in macroinvertebrate abundance will have ripple effects throughout other trophic levels (Brönmark \& Weisner, 1992). Populations of species using macrophytes for habitat and refuge may have to relocate to find suitable habitat elsewhere (Wolcox \& Meeker, 1992). In addition to increased grazing by crayfish, the present study found changes in selectivity of that grazing which produces changes in relative abundance that alter macrophyte community diversity.

Crayfish are known to be selective in the herbivory component of their diet (Chambers, Hanson, \& Prepas, 1991; Cronin et al., 2002; Nyström \& Strand, 1996). Uneven consumption of macrophytes under threat of predation may lead to shifts in relative abundances due to increased herbivory pressure on preferred species. Changes in macrophyte diversity have the potential to alter the effectiveness of ecosystem services provided by littoral zone macrophyte communities (Carpenter \& Lodge, 1986) especially through changes in spatial heterogeneity of macrophyte bed habitats. Spatial heterogeneity is an important component of habitat quality in aquatic environments, which contributes to the diversity of animals a habitat can support (Heck \& Crowder, 1991; Pianka, 1966). For example, benthic mats of Chara spp. often support a higher abundance of macroinvertebrates than vascular aquatic plants do (Waters \& San Giovanni, 2002). These mats of vegetation grow in shallow water, are dense, and highly complex, thus providing a good refuge from predators while also allowing access to accumulated detritus and Chara spp. tissue as food resources.

The observed changes in either macrophyte abundance or diversity are a result of a negative indirect effect of an aquatic predator on macrophyte communities. Typically, nonconsumptive effects of predators have been found to reduce the impact of foraging by prey (Fortin, Boyce, Merrill, \& Fryxell, 2004; Lima \& Dill, 1990; Turner \& Mittelbach, 1990). These reductions in foraging drive the indirect effects of predator presence on the plant community. For example, in coastal marine environments, the presence of predatory crabs (Carcinus maenas) has been shown to reduce grazing pressure on fucoid algae (Ascophyllum nodosum) by snails (Littorina littorea), allowing increased algal growth (Trussell et al., 2017). However, in the present study, the direct observations of increased macrophyte consumption under threat of predation suggest that more complicated interactions may be at play, at least in this system.

The appearance of macrophyte preferences by crayfish under predation threat implies that the nonconsumptive effect of the predator alters the perceived value of each macrophyte as a food resource. Other studies have found that prey will switch their food preferences under threat to either recoup energetic costs or reduce handling time (Hay \& Fuller, 1981; Lima \& Dill, 1990; Schmitz, Beckerman, \& O'Brien, 1997). Although not directly measured here, changes in foraging choices may be based on differences in plant morphology, nutritional content and/or buoyancy (Chambers et al., 1991; Cronin et al., 2002; Lodge, 1991). Thus, handling time may carry more weight for crayfish foraging decisions under predation threats. Physiological changes, such as plant defensive chemicals, may also be involved in the choice. Crayfish are known to prefer plants with lower noxious chemical content (Bolser et al., 1998; Chambers et al., 1991; Cronin et al., 2002). In the present study, chemical analyses for total phenolic content were performed on a small subset of the macrophyte samples $(n=5)$. Myriophyllum exalbescens showed significantly higher phenolic content in control treatments than either E. canadensis or Chara spp. Despite the lack of any systematic changes in plant phenolics in any of the bass or crayfish treatments, the greater loss of biomass seen in the two plant species with lower phenolic content may be evidence that crayfish are using the concentration of phenolics to make foraging decisions in the presence of predatory odours.

\section{5 | CONCLUSIONS}

The responses of prey species to predator stimuli are complex and difficult to predict. The increase in foraging activity and plant consumption by crayfish in this study did not match our predictions. The results do provide insight into how the presence of aquatic predators can have indirect effects on macrophyte communities, 
thus linking two trophic levels that typically do not interact directly (Abrams, 1995). In streams where both crayfish and bass are present, the abundance of macrophytes is likely to be reduced, causing a loss in valuable food resources and refugia for other invertebrates, fishes, waterfowl and mammals. However, reductions in macrophyte abundance may be beneficial to stream life if macrophyte stands become too large or too dense. The appearance of foraging preferences under threat of predation also changes the way that predators and prey interact with other species in the community. If a predatory threat causes crayfish to focus their foraging efforts on E. canadensis and Chara spp. in streams, the growth of other macrophyte species responding to the selective grazing might alter the diversity of the macrophyte community. Macrophyte diversity is especially important in stream environments because of the high degree of interconnectivity between species found there (Brown, Edwards, Milner, Woodward, \& Ledger, 2011). Crayfish function as keystone species in aquatic environments (Crandall \& Buhay, 2008) and can thus produce disproportionately large changes in community structure when their behaviour or abundance is altered. Understanding the nuances of predator-prey interactions is vital to our ability to predict the outcome of human manipulations of stream environments and to better inform our conservation and management efforts.

\section{ACKNOWLEDGMENTS}

The authors would like to thank the members of the Laboratory for Sensory Ecology for their assistance in the experimental set-up, collection of crayfish and review of this manuscript. We would like to thank Tim Veverica for running the plant chemistry analysis. We would also like to thank the University of Michigan Biological Station for the use of facilities and funding through the Marian P. and David M. Gates Graduate Student Endowment Fund to T.C.W. Lastly, we would like to thank the Bowling Green State University Faculty Research Committee for a Building Strength Award and the Fulbright Fellowship to P.A.M. for help in funding this research.

\section{ETHICAL APPROVAL}

All bass were maintained following established animal care and use procedures. Use of animals in this experiment was approved by the Institutional Care and Use Committees at Bowling Green State University (Protocol: 856543-5) and the University of Michigan (Protocol: PRO00006840).

\section{CONFLICT OF INTEREST}

The authors have no conflict of interests to declare.

\section{ORCID}

Tyler C. Wood (iD http://orcid.org/0000-0002-1455-1167

\section{REFERENCES}

Abrahamsson, S. A. A. (1966). Dynamics of an isolated population of the crayfish Astacus astacus Linné. Oikos, 17(1), 96-107. https://doi.org/ $10.2307 / 3564784$

Abrams, P. A. (1995). Implications of dynamically variable traits for identifying, classifying, and measuring direct and indirect effects in ecological communities. The American Naturalist, 146(1), 112-134. https:// doi.org/10.1086/285789

Atema, J. (1988). Distribution of chemical stimuli. In J. Atema, R. R. Fay, A. N. Popper, \& W. N. Tavolga (Eds.), Sensory biology of aquatic animals (pp. 29-56). New York, NY: Springer. https://doi.org/10.1007/ 978-1-4612-3714-3

Barton, B. A. (2002). Stress in Fishes: A diversity of responses with particular reference to changes in circulating corticosteroids1. Integrative and Comparative Biology, 42(3), 517-525. https://doi.org/10.1093/ $\mathrm{icb} / 42.3 .517$

Bates, D., Maechler, M., Bolker, B., \& Walker, S. (2015). Fitting linear mixed-effects models using Ime4. Journal of Statistical Software, 67(1), 1-48. https://doi.org/10.18637/jss.v067.i01

Bolser, R. C., Hay, M. E., Lindquist, N., Fenical, W., \& Wilson, D. (1998). Chemical defenses of freshwater macrophytes against crayfish herbivory. Journal of Chemical Ecology, 24(10), 1639-1658. https://doi. org/10.1023/A:1020816511924

Bouwma, P., \& Hazlett, B. A. (2001). Integration of multiple predator cues by the crayfish Faxonius propinquus. Animal Behaviour, 61(4), 771776. https://doi.org/10.1006/anbe.2000.1649

Brönmark, C. (1990). How do herbivorous freshwater snails affect macrophytes?-A comment. Ecology, 71(3), 1212-1215. https://doi.org/10. 2307/1937391

Brönmark, C., \& Hansson, L.-A. (2000). Chemical communication in aquatic systems: An introduction. Oikos, 88(1), 103-109. https://doi.org/ 10.1034/j.1600-0706.2000.880112.x

Brönmark, C., \& Miner, J. G. (1992). Predator-induced phenotypical change in body morphology in crucian carp. Science, 258(5086), 1348-1350. https://doi.org/10.1126/science.258.5086.1348

Brönmark, C., \& Weisner, S. (1992). Indirect effects of fish community structure on submerged vegetation in shallow, eutrophic lakes - an alternative mechanism. Hydrobiologia, 243(1), 293-301. https://doi. org/10.1007/BF00007045

Brown, L. E., Edwards, F. K., Milner, A. M., Woodward, G., \& Ledger, M. E. (2011). Food web complexity and allometric scaling relationships in stream mesocosms: Implications for experimentation. Journal of Animal Ecology, 80(4), 884-895. https://doi.org/10.1111/j.13652656.2011.01814.x

Brown, J. S., Laundré, J. W., \& Gurung, M. (1999). The ecology of fear: Optimal foraging, game theory, and trophic interactions. Journal of Mammalogy, 80(2), 385-399. https://doi.org/10.2307/ 1383287

Carpenter, S. R., \& Lodge, D. M. (1986). Effects of submersed macrophytes on ecosystem processes. Aquatic Botany, 26, 341-370. https://doi.org/10.1016/0304-3770(86)90031-8

Carreira, B. M., Dias, M. P., \& Rebelo, R. (2014). How consumption and fragmentation of macrophytes by the invasive crayfish Procambarus clarkii shape the macrophyte communities of temporary ponds. Hydrobiologia, 721(1), 89-98. https://doi.org/10.1007/s10750-0131651-1

Carreira, B. M., Segurado, P., Laurila, A., \& Rebelo, R. (2017). Can heat waves change the trophic role of the world's most invasive crayfish? Diet shifts in Procambarus clarkii PLoS ONE, 12(9), e0183108. https://doi.org/10.1371/journal.pone.0183108

Chambers, P. A., Hanson, J. M., \& Prepas, E. E. (1991). The effect of aquatic plant chemistry and morphology on feeding selectivity by the crayfish, Faxonius virilis. Freshwater Biology, 25(2), 339-348. https:// doi.org/10.1111/j.1365-2427.1991.tb00496.x 
Chibucos, K., Wofford, S. J., \& Moore, P. A. (2015). Hierarchical decision making: Resource distribution exhibits stronger effect on crayfish dominance relationships and shelter occupation than prior social experience and resource ownership. Behaviour, 152(7-8), 1063-1082. https://doi.org/10.1163/1568539X-00003292

Chivers, D. P., Wisenden, B. D., \& Smith, R. J. F. (1996). Damselfly larvae learn to recognize predators from chemical cues in the predator's diet. Animal Behaviour, 52(2), 315-320. https://doi.org/10.1006/anbe. 1996.0177

Crandall, K. A., \& Buhay, J. E. (2008). Global diversity of crayfish (Astacidae, Cambaridae, and Parastacidae-Decapoda) in freshwater. Hydrobiologia, 595(1), 295-301. https://doi.org/10.1007/s10750007-9120-3

Cronin, G., Lodge, D. M., Hay, M. E., Miller, M., Hill, A. M., Horvath, T., ... Wahl, M. (2002). Crayfish feeding preferences for freshwater macrophytes: The influence of plant structure and chemistry. Journal of Crustacean Biology, 22(4), 708-718. https://doi.org/10.1651/02780372(2002)022[0708:CFPFFM]2.0.CO;2

Derby, C. D., \& Sorensen, P. W. (2008). Neural processing, perception, and behavioral responses to natural chemical stimuli by fish and crustaceans. Journal of Chemical Ecology, 34(7), 898-914. https://doi.org/ 10.1007/s10886-008-9489-0

Feminella, J. W., \& Resh, V. H. (1989). Submersed macrophytes and grazing crayfish: An experimental study of herbivory in a California freshwater marsh. Holarctic Ecology, 12(1), 1-8.

Folin, O., \& Ciocalteu, V. (1927). On tyrosine and tryptophane determinations in proteins. Journal of Biological Chemistry, 73(2), 627-650.

Fortin, D., Boyce, M. S., Merrill, E. H., \& Fryxell, J. M. (2004). Foraging costs of vigilance in large mammalian herbivores. Oikos, 107(1), 172 180. https://doi.org/10.1111/j.0030-1299.2004.12976.x

Gherardi, F., \& Acquistapace, P. (2007). Invasive crayfish in Europe: The impact of Procambarus clarkii on the littoral community of a Mediterranean lake. Freshwater Biology, 52(7), 1249-1259. https://doi.org/ 10.1111/j.1365-2427.2007.01760.x

Gherardi, F., Mavuti, K. M., Pacini, N. I. C., Tricarico, E., \& Harper, D. M. (2011). The smell of danger: Chemical recognition of fish predators by the invasive crayfish Procambarus clarkii. Freshwater Biology, 56(8), 1567-1578. https://doi.org/10.1111/j.1365-2427.2011.02595.x

Grabowski, J. H. (2004). Habitat complexity disrupts predator-prey interactions but not the trophic cascade on oyster reefs. Ecology, 85(4), 995-1004. https://doi.org/10.1890/03-0067

Gresens, S. E. (1995). Grazer diversity, competition and the response of the periphyton community. Oikos, 73, 336-346. https://doi.org/10. $2307 / 3545957$

Hambright, K. D. (1991). Experimental analysis of prey selection by largemouth bass: Role of predator mouth width and prey body depth. Transactions of the American Fisheries Society, 120(4), 500-508. https://doi.org/10.1577/1548-8659(1991)120<0500:EAOPSB > 2.3.CO;2

Hawlena, D., \& Schmitz, O. J. (2010). Physiological stress as a fundamental mechanism linking predation to ecosystem functioning. The American Naturalist, 176(5), 537-556. https://doi.org/10.1086/656495

Hay, M. E., \& Fuller, P. J. (1981). Seed escape from heteromyid rodents: The importance of microhabitat and seed preference. Ecology, 62(5), 1395-1399. https://doi.org/10.2307/1937304

Hay, M. E., \& Kubanek, J. (2002). Community and ecosystem level consequences of chemical cues in the plankton. Journal of chemical ecology, 28(10), 2001-2016. https://doi.org/10.1023/A:1020797827806

Hazlett, B. A., \& Schoolmaster, D. R. (1998). Responses of cambarid crayfish to predator odor. Journal of Chemical Ecology, 24(11), 17571770. https://doi.org/10.1023/A:1022347214559

Heck, K. L., \& Crowder, L. B. (1991). Habitat structure and predatorprey interactions in vegetated aquatic systems. In S. S. Bell, E. D. McCoy, \& H. R. Mushinsky (Eds.), Habitat structure (pp. 281-299). Dordrecht, the Netherlands: Springer. https://doi.org/10.1007/97894-011-3076-9
Hill, J. M., \& Weissburg, M. J. (2013). Predator biomass determines the magnitude of non-consumptive effects (NCEs) in both laboratory and field environments. Oecologia, 172(1), 79-91. https://doi.org/10. 1007/s00442-012-2488-4

Hogger, J. B. (1988). Ecology, population biology and behaviour. In D. M. Holdich, \& R. S. Lowery (Eds.), Freshwater crayfish: Biology, management and exploitation (pp. 114-144). London, UK: Croom Helm Ltd.

Hothorn, T., Bretz, F., \& Westfall, P. (2008). Simultaneous inference in general parametric models. Biometrical Journal, 50(3), 346-363. https://doi.org/10.1002/(ISSN)1521-4036

Jurcak, A. M., \& Moore, P. A. (2014). Behavioral decisions in sensory landscapes: Crayfish use chemical signals to make habitat use choices. Journal of Crustacean Biology, 34(5), 559-564. https://doi. org/10.1163/1937240X-00002266

Keller, T. A., Tomba, A. M., \& Moore, P. A. (2001). Orientation in complex chemical landscapes: Spatial arrangement of chemical sources influences crayfish food-finding efficiency in artificial stream. Limnology and Oceanography, 46(2), 238-247. https://doi.org/10.4319/lo.2001. 46.2.0238

Lamberti, G. A., Ashkenas, L. R., Gregory, S. V., \& Steinman, A. D. (1987). Effects of three herbivores on periphyton communities in laboratory streams. Journal of the North American Benthological Society, 6(2), 92 104. https://doi.org/10.2307/1467219

Laundré, J. W., Hernández, L., \& Ripple, W. J. (2010). The landscape of fear: Ecological implications of being afraid. Open Ecology Journal, 3, 1-7. https://doi.org/10.2174/1874213001003030001

Lima, S. L., \& Dill, L. M. (1990). Behavioral decisions made under the risk of predation: A review and prospectus. Canadian Journal of Zoology, 68(4), 619-640. https://doi.org/10.1139/z90-092

Lodge, D. M. (1991). Herbivory on freshwater macrophytes. Aquatic Botany, 41(1-3), 195-224. https://doi.org/10.1016/0304-3770(91) 90044-6

Lodge, D. M., Kershner, M. W., Aloi, J. E., \& Covich, A. P. (1994). Effects of an omnivorous crayfish (Faxonius rusticus) on a freshwater littoral food web. Ecology, 75(5), 1265-1281. https://doi.org/10.2307/ 1937452

Lodge, D. M., \& Lorman, J. G. (1987). Reductions in submersed macrophyte biomass and species richness by the crayfish Faxonius rusticus. Canadian Journal of Fisheries and Aquatic Sciences, 44(3), 591-597. https://doi.org/10.1139/f87-072

Luttbeg, B., \& Trussell, G. C. (2013). How the informational environment shapes how prey estimate predation risk and the resulting indirect effects of predators. The American Naturalist, 181(2), 182-194. https://doi.org/10.1086/668823

Moore, P., \& Crimaldi, J. (2004). Odor landscapes and animal behavior: Tracking odor plumes in different physical worlds. Journal of Marine Systems, 49(1-4), 55-64. https://doi.org/10.1016/j.jmarsys.2003.05.005

Moretto, A. S., \& Distel, R. A. (1999). Effects of selective defoliation on the competitive interaction between palatable and unpalatable grasses native to a temperate semi-arid grassland of Argentina. Journal of Arid Environments, 42(3), 167-175. https://doi.org/10.1006/ja re.1999.0510

Nilsson, P. A., Brönmark, C., \& Pettersson, L. B. (1995). Benefits of a predator-induced morphology in crucian carp. Oecologia, 104(3), 291 296. https://doi.org/10.1007/BF00328363

Nyström, P., \& Strand, J. (1996). Grazing by a native and an exotic crayfish on aquatic macrophytes. Freshwater Biology, 36(3), 673-682. https://doi.org/10.1046/j.1365-2427.1996.d01-508.x

Parsons, A. J., Harvey, A., \& Johnson, I. R. (1991). Plant-animal interactions in a continuously grazed mixture. II. The role of differences in the physiology of plant growth and of selective grazing on the performance and stability of species in a mixture. Journal of Applied Ecology, 28(2), 635-658. https://doi.org/10.2307/2404573

Pauwels, K., Stoks, R., \& De Meester, L. (2005). Coping with predator stress: Interclonal differences in induction of heat-shock proteins in 
the water flea Daphnia magna. Journal of evolutionary biology, 18(4), 867-872. https://doi.org/10.1111/j.1420-9101.2005.00890.x

Peacor, S. D., Peckarsky, B. L., Trussell, G. C., \& Vonesh, J. R. (2013). Costs of predator-induced phenotypic plasticity: A graphical model for predicting the contribution of nonconsumptive and consumptive effects of predators on prey. Oecologia, 171(1), 1-10. https://doi.org/ 10.1007/s00442-012-2394-9

Peacor, S. D., \& Werner, E. E. (2001). The contribution of trait-mediated indirect effects to the net effects of a predator. Proceedings of the National Academy of Sciences of the United States of America, 98(7), 3904-3908. https://doi.org/10.1073/pnas.071061998

Persons, M. H., \& Rypstra, A. L. (2001). Wolf spiders show graded antipredator behavior in the presence of chemical cues from different sized predators. Journal of Chemical Ecology, 27(12), 2493-2504. https://doi.org/10.1023/A:1013679532070

Pianka, E. R. (1966). Latitudinal gradients in species diversity: A review of concepts. The American Naturalist, 100(910), 33-46. https://doi.org/ $10.1086 / 282398$

Power, M. E., \& Matthews, W. J. (1983). Algae-grazing minnows (Campostoma anomalum), piscivorous bass (Micropterus spp.), and the distribution of attached algae in a small prairie-margin stream. Oecologia, 60(3), 328-332. https://doi.org/10.1007/BF00376847

Preisser, E. L., Bolnick, D. I., \& Benard, M. F. (2005). Scared to death? The effects of intimidation and consumption in predator-prey interactions. Ecology, 86(2), 501-509. https://doi.org/10.1890/04-0719

$R$ Core Team (2018). $R$ : A language and environment for statistical computing. Vienna, Austria: R Foundation for Statistical Computing. http:// www.R-project.org/

Ripple, W. J., \& Beschta, R. L. (2006). Linking wolves to willows via risksensitive foraging by ungulates in the northern Yellowstone ecosystem. Forest Ecology and Management, 230(1-3), 96-106. https://doi. org/10.1016/j.foreco.2006.04.023

Rodríguez, C. F., Bécares, E., Fernández-Aláez, M., \& Fernández-Aláez, C. (2005). Loss of diversity and degradation of wetlands as a result of introducing exotic crayfish. Biological Invasions, 7(1), 75. https://doi. org/10.1007/s10530-004-9636-7

Schmitz, O. J. (1998). Direct and indirect effects of predation and predation risk in old-field interaction webs. The American Naturalist, 151(4), 327-342. https://doi.org/10.1086/286122

Schmitz, O. J., Beckerman, A. P., \& O'Brien, K. M. (1997). Behaviorally mediated trophic cascades: Effects of predation risk on food web interactions. Ecology, 78(5), 1388-1399. https://doi.org/10.1890/ 0012-9658(1997)078[1388:BMTCEO]2.0.CO;2

Sheriff, M. J., Krebs, C. J., \& Boonstra, R. (2009). The sensitive hare: Sublethal effects of predator stress on reproduction in snowshoe hares. Journal of Animal Ecology, 78(6), 1249-1258. https://doi.org/10. 1111/j.1365-2656.2009.01552.x

Sih, A. (1982). Foraging strategies and the avoidance of predation by an aquatic insect, Notonecta hoffmanni. Ecology, 63(3), 786-796. https://doi.org/10.2307/1936799

Soszka, G. J. (1975). Ecological relations between invertebrates and submerged macrophytes in the lake littoral. Ekologia Polska, 23, 393-415.

Taniguchi, H., Nakano, S., \& Tokeshi, M. (2003). Influences of habitat complexity on the diversity and abundance of epiphytic invertebrates on plants. Freshwater Biology, 48(4), 718-728. https://doi.org/10. 1046/j.1365-2427.2003.01047.x

Tollrian, R. (1995). Predator-induced morphological defenses: Costs, life history shifts, and maternal effects in Daphnia pulex. Ecology, 76(6), 1691-1705. https://doi.org/10.2307/1940703
Trussell, G. C., Ewanchuk, P. J., \& Bertness, M. D. (2003). Trait-mediated effects in rocky intertidal food chains: Predator risk cues alter prey feeding rates. Ecology, 84(3), 629-640. https://doi.org/10.1890/ 0012-9658(2003)084[0629:TMEIRI]2.0.CO;2

Trussell, G. C., Matassa, C. M., \& Ewanchuk, P. J. (2017). Moving beyond linear food chains: trait-mediated indirect interactions in a rocky intertidal food web. Proc. R. Soc. B, 284(1851), 20162590

Turner, A. M. (2008). Predator diet and prey behaviour: Freshwater snails discriminate among closely related prey in a predator's diet. Animal Behaviour, 76(4), 1211-1217. https://doi.org/10.1016/j.an behav.2008.06.005

Turner, A. M., Fetterolf, S. A., \& Bernot, R. J. (1999). Predator identity and consumer behavior: Differential effects of fish and crayfish on the habitat use of a freshwater snail. Oecologia, 118(2), 242-247. https://doi.org/10.1007/s004420050724

Turner, A. M., \& Mittelbach, G. G. (1990). Predator avoidance and community structure: Interactions among piscivores, planktivores, and plankton. Ecology, 71(6), 2241-2254. https://doi.org/10.2307/ 1938636

Turner, A. M., \& Peacor, S. D. (2012). Scaling up infochemicals: Ecological consequences of chemosensory assessment of predation risk. In C. Brönmark \& L.-A. Hansson (Eds.), Chemical ecology in aquatic systems (pp. 140-157). Oxford, UK: Oxford University Press. https://doi.org/ 10.1093/acprof:osobl/9780199583096.001.0001

Urban, M. C. (2007). The growth-predation risk trade-off under a growing gape-limited predation threat. Ecology, 88(10), 2587-2597. https://doi.org/10.1890/06-1946.1

Wallace, J. B., \& Webster, J. R. (1996). The role of macroinvertebrates in stream ecosystem function. Annual Review of Entomology, 41(1), 115139. https://doi.org/10.1146/annurev.en.41.010196.000555

Warfe, D. M., \& Barmuta, L. A. (2006). Habitat structural complexity mediates food web dynamics in a freshwater macrophyte community. Oecologia, 150(1), 141-154. https://doi.org/10.1007/s00442-006-0505-1

Waters, N. M., \& San Giovanni, C. R. (2002). Distribution and diversity of benthic macroinvertebrates associated with aquatic macrophytes. Journal of Freshwater Ecology, 17(2), 223-232. https://doi.org/10. 1080/02705060.2002.9663890

Weissburg, M., Poulin, R. X., \& Kubanek, J. (2016). You are what you eat: A metabolomics approach to understanding prey responses to dietdependent chemical cues released by predators. Journal of Chemical Ecology, 42(10), 1037-1046. https://doi.org/10.1007/s10886-0160771-2

Wolcox, D. A., \& Meeker, J. E. (1992). Implications for faunal habitat related to altered macrophyte structure in regulated lakes in northern Minnesota. Wetlands, 12(3), 192-203. https://doi.org/10.1007/ BF03160609

How to cite this article: Wood TC, Kelley RE, Moore PA. Feeding in fear: Indirect effects of predatory fish on macrophyte communities mediated by altered crayfish foraging behaviour. Freshwater Biol. 2018;63:1523-1533. https://doi.org/10.1111/fwb.13181 